\title{
KADAR AIR, KUALITAS FISIK BIJI DAN SERANGAN CENDAWAN PASCAPANEN PADA KACANG TANAH YANG DIPEROLEH DARI PASAR TRADISIONAL CIAMPEA BOGOR
}

\author{
Nur Antriana \\ STIKES Harapan Ibu Jambi \\ Jl. Tarmizi Kadir No 71 Pakuan Baru Thehok, Jambi 36132 \\ Email: antreemik12@gmail.com
}

\begin{abstract}
Abstrak: Kacang tanah merupakan bahan pangan yang banyak dikonsumsi oleh masyarakat Indonesia, namun pengolahan pascapanen yang kurang tepat menyebabkan turunnya kualitas karena sangat rentan terserang cendawan pascapanen. Penelitian ini bertujuan menentukan kadar air, persentase biji rusak, spesies cendawan pascapanen, persentase biji yang terserang oleh setiap spesies cendawan pascapanen pada biji kacang tanah yang diperoleh dari pasar tradisional Ciampe Bogor. Jumlah sampel biji kacang tanah mentah sebanyak tiga sampel yaitu KTA, KTB, dan KTC. Kualitas fisik biji ditentukan berdasarkan persentase biji utuh, biji keriput, dan biji rusak. Penentuan kadar air menggunakan DELMHORST Model G-7 Mouisture Meter. Metode yang digunakan menentukan persentase biji kacang tanah yang terserang cendawan adalah metode penanaman langsung menggunakan media Dichloran 18\% Glycerol Agar (DG18+) dan media Aspergillus Flavus and Parasiticus Agar (AFPA). Hasilnya menunjukkan persentase biji yang rusak pada sampel KTA, KTB dan KTC berturut-turut sebagai berikut: $41 \%$, 50\%, dan 30.7\%. Kadar air pada sampel kacang tanah KTA, KTB dan KTC berturut-turut sebagai berikut: 6.95, 6.70, dan 8.00. Persentase biji kacang tanah yang terserang cendawan didominasi oleh beberapa spesies antara lain Aspergillus flavus, A. niger, Eurotium chevalieri, dan Synchepalastrum rasemosum.
\end{abstract}

Kata Kunci: Kualitas Kacang Tanah, Cendawan Pascapanen, Pasar Tradisional

\section{THE WATER LEVEL, PHYSICAL QUALITIES SEEDS AND ATTACKS FUNGI AFTER THE HARVEST ON THE NUTS LAND ACQUIRED FROM TRADITIONAL MARKET CIAMPEA BOGOR}

Abstract: Peanut is groceries that are mostly consumed by the indonesian people, but a bad time processing pascapanen caused decreases in quality because very fragile pascapanen with mushroom. This study aims to determine the moisture content of , the percentage of broken, after the harvest fungal species, the percentage of be stricken by any species of mushroom after the harvest on the seeds of land acquired from traditional 
markets Ciampe Bogor. The total sample the seeds of ground raw in three sample that is KTA, KTB, and KTC. Physical qualities seeds determined based on the percentage seeds whole, seeds wrinkles, and seeds damaged. The determination of the water level use delmhorst model g-7 mouisture meters. Methods used determine the percentage seeds of the land with boletus is the method planting by using media dichloran $18 \%$ glycerol from it and dg18 + and media aspergillus flavus and parasiticus from it afpa. The results show the percentage seeds which damaged on sample kta, ktb and ktc successive as follows: $41 \%, 50 \%$, and $30.7 \%$. The water level in samples of peanut KTA, KTB and KTC successive as follows: $6.95,6.70$, and 8.00 . The percentage seeds of the land with boletus dominated by some species among others Aspergillus flavus, A. niger, Eurotium chevalieri, and Synchepalastrum rasemosum.

\section{Keywords: Nuts Quality, Fungi, Traditional Market}

Kacang tanah (Arachis hypogaea) merupakan salah satu bahan pangan yang banyak dikonsumsi di Indonesia. Dalam proses pascapanen biji kacang tanah sangat rentan terserang cendawan pascapanen. Hal ini disebabkan karena kurangnya penanganan pascapanen yang dilakukan oleh petani dan pedagang kacang tanah (Wang \& Liu, 2007) serta faktor lain yaitu kondisi lingkungan, seperti suhu dan kelembaban, serta sirkulasi udara dalam ruang penyimpanan (Rachmawati, 2012). Cendawan pascapanen yang umumnya menyerang biji kacang tanah menghasilkan mikotoksin yang dihasilkan oleh genus Aspergillus, Penicillium, Rhizopus dan Fusarium. A. flavus dan A. parasiticus merupakan cendawan utama penghasil aflatoksin B1, B2, G1, dan G2 (Didwania dan Joshi, 2013). Kacang tanah yang diserang oleh cendawan dapat mengakibatkan penurunan kualitas fisik yang ditandai dengan adanya perubahan struktur hingga morfologi kacang tanah seperti perubahan warna, biji menjadi kisut dan retak.

Aflatoksin yang dihasilkan oleh Aspergillus merupakan mikotoksin yang banyak ditemukan pada makanan dan olahannya seperti kacang-kacangan, jagung, gandum, daging, dan susu (Patino et al., 2005). Aflatoksin yang dihasilkan oleh Aspergillus flavus yaitu aflatkosin B1 dan B2 dimana aflatoksin B1 merupakan jenis aflatoksin yang paling beracun dan berbahaya (Duran et al., 2009). Kontaminasi aflatoksin pada bahan pangan berawal dari petani, kemudian meningkat selama penyimpanan oleh pedagang pengumpul (Kusumaningrum et al., 2010). Aflatoksin yang dihasilkan oleh Aspergillus flavus yaitu aflatkosin B1 dan B2 dimana aflatoksin B1 merupakan jenis aflatoksin yang paling beracun dan berbahaya (Duran et al., 2009). Paramawati (2006) melaporkan bahwa kandungan aflatoksin pada berbagai pasar di empat kabupaten di provinsi Lampung menunjukkan paparan kontaminasi aflatoksin B1 pada kacang tanah bervariasi dari 4,4 sampai 205 ppb dengan rata-rata kontaminasi 69.76 ppb. Di Indonesia batas maksimum kandungan aflatoksin B1 pada kacang tanah ialah 15 ppb (SNI, 2009). Standar tersebut 
merupakan kriteria mutu kacang tanah yang ditetapkan oleh Badan Standardisasi Nasional (BSN).

Senyawa metabolit sekunder yang dihasilkan oleh A. flavus dapat menyebabkan berbagai pengaruh yaitu timbulnya penyakit seperti hepatocarcinoma (aflatoksin akut), kwashiorkor, dan kanker hati (Kuniholm et al., 2008). Selain itu, Aflatoksin yang dihasilkan oleh Aspergillus flavus, Aspergillus parasiticus, dan cendawan lainnya adalah metabolit sekunder dengan karsinogenik, estrogenik, teratogenik, dan efek imunosupresif (Klich et al., 2009). Kontaminasi aflatoksin dapat dicegah dengan manajemen sistem prapanen hingga pascapanen yang tepat salah satunya adalah penyimpanan kacang tanah yang segera dikeringkan hingga kadar air biji kurang dari 9\%, disimpan pada wadah kedap udara dalam ruangan bersih dengan ventilisi baik (Kasno, 2009) dan menurunkan populasi serangga yang berperan sebagai jalan masuk cendawan dan perantara penyebaran sporanya (Antika et al., 2014). Berdasarkan pemaparan di atas pengujian kualitas kacang tanah meliputi kadar air, persentase biji rusak, spesies cendawan pascapanen, dan persentase biji yang terserang oleh setiap spesies cendawan pascapanen) yang diperoleh dari pasar tradisional Ciampea Bogor perlu dilakukan.

\section{METODE PENELITIAN}

Sebanyak 500 gram biji kacang tanah yang diperoleh dari Pasar Ciampea bogor yaitu KTA, KTB, dan KTC telah dibagi dua kali dengan pembagi sampel berbentuk boks (box sample divider) untuk memperoleh sampel kerja. Sampel kerja diberi kode sampel a, b, c dan d. Sampel kerja berkode a dan c sejumlah masing-masing 125 gram digunakan untuk menentukan persentase biji rusak. Sampel kerja berkode b dan d sejumlah masingmasing 125 gram digunakan untuk menentukan persentase biji yang terserang cendawan. Penentuan kadar air. Setiap sampel kacang tanah ditentukan kadar airnya dengan menggunakan DELMHORST Model G-7 Mouisture Meter. Alat tersebut telah dikalibrasi dan dicek silang dengan menggunakan metode oven. Setiap sampel dibuat dua ulangan dengan bobot 170 gram untuk setiap ulangan.

Penentuan persentase biji rusak. Ciri-ciri biji rusak antara lain : biji retak, biji patah, biji keriput, biji berubah warna, biji terserang serangga, dan biji yang secara visual dapat dilihat terserang cendawan. Jumlah biji dari setiap sampel yang akan digunakan yaitu 100 biji. Persentase biji rusak akan ditentukan dengan rumus sebagai berikut: Penentuan persentase biji kacang tanah yang terserang cendawan. Metode yang digunakan adalah metode penanaman langsung. Sebanyak 100 biji kacang tanah baik yang utuh maupun rusak didesinfeksi dengan Na-hipoklorit 1\% selama satu menit kemudian seluruh biji dikeringkan dengan kertas saring steril di dalam cawan petri. Media yang digunakan adalah media Dichloran 18\% Glycerol Agar (DG18+) dan media Aspergillus Flavus and Parasiticus Agar (AFPA). Kedua media mengandung antibiotik kloramfenikol. Sebanyak 10 biji kacang tanah diletakkan di dalam satu media sehingga 
diperoleh masing-masing 50 biji kacang tanah untuk lima media DG18 dan lima media AFPA. Cawan petri diinkubasi pada suhu ruang selama 5-7 hari untuk media DG18+ dan 4 hari untuk media AFPA. Pada media DG18+ koloni setiap spesies cendawan yang dibedakan atas warna dan pola pertumbuhannya dipindahkan ke media Czapex Yeast Extract Agar (CYA) atau Czapex Yeast Extract Agar dengan 20\% sukrosa (CY20S). Cendawan yang tumbuh diidentifikasi berdasarkan Pitt dan Hocking (1997), pada media AFPA, koloni Aspergillus flavus berwarna kuning keoranyean di bagian bawah cawan petri. Persentase biji yang teserang cendawan di media DG18+ dan FPA masing-masing dihitung

\section{HASIL DAN PEMBAHASAN}

Produk pertanian yang akan disimpan, terutama biji-bijian sebaiknya dikeringkan sampai dengan kadar air yang sesuai untuk penyimpanan. Kadar air dan persentase biji yang rusak untuk KTA, KTB dan KTC berturut-turut sebagai berikut: 41\%, 50\%, dan 30.7\%

Tabel 1 Penentuan kadar air dan persentase biji rusak kacang tanah

\begin{tabular}{|c|c|c|c|c|}
\hline Jenis & \multicolumn{3}{|c|}{ Kadar Air } & Biji \\
\hline $\begin{array}{c}\text { Kacang } \\
\text { Tanah }\end{array}$ & U1 & $\mathrm{U} 2$ & Rataan & $\begin{array}{c}\text { Rusak } \\
(\%)\end{array}$ \\
\hline KTA & 7.0 & 6.9 & 6.95 & 41.0 \\
\hline KTB & 6.8 & 6.6 & 6.70 & 50.0 \\
\hline KTC & 8.0 & 8.0 & 8.00 & 30.7 \\
\hline
\end{tabular}

Persentase biji kacang tanah yang terserang cendawan didominasi oleh beberapa spesies antara lain Aspergillus flavus, A. niger, Eurotium chevalieri, dan Synchepalastrum rasemosum. Cendawan yang menyerang jenis kacang tanah KTA dan KTC dengan persentase tertinggi adalah cendawan Aspergillus niger sedangkan cendawan yang menyerang jenis kacang tanah KTB dengan persentase tertinggi adalah cendawan Eurotium chevalieri.

Tabel 2 Persentase biji kacang tanah yang terserang cendawan

\begin{tabular}{lccr}
\hline \multirow{2}{*}{ Cendawan } & \multicolumn{3}{c}{ Biji terserang } \\
\cline { 2 - 4 } & KTA & KTB & KTC \\
\hline Aspergillus flavus & 22 & 3 & 10 \\
A. niger & 84 & 63 & 75 \\
Eurotium chevalieri & 38 & 100 & 20 \\
Synchepalastrum & 64 & - & 10 \\
rasemosum & & & \\
\hline
\end{tabular}




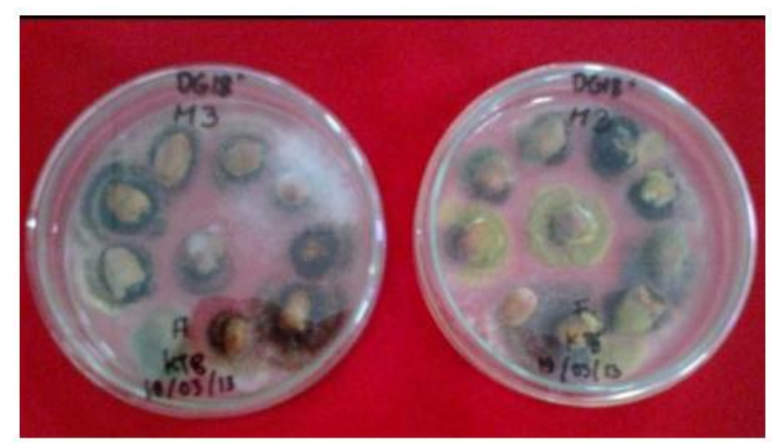

Gambar 1. Isolasi cendawan pascapanen dari biji kacang tanah pada media DG18+

Konidiofor A. niger memiliki panjang tangkai 1-3 mm, dinding hialin dan halus; vesikula bulat, biasanya berdiameter $50-75 \mu \mathrm{m}$, membentuk metula dan fialid yang rapat pada seluruh permukaannya, panjang metula $10-15 \mu \mathrm{m}$, panjang fialid 7-10 $\mu \mathrm{m}$; konidium bulat, diameter 4-5 $\mu \mathrm{m}$, berwarna coklat, berdinding kasar atau kadang-kadang terdapat goresan, dibentuk di dalam kepala yang besar dan radiate.

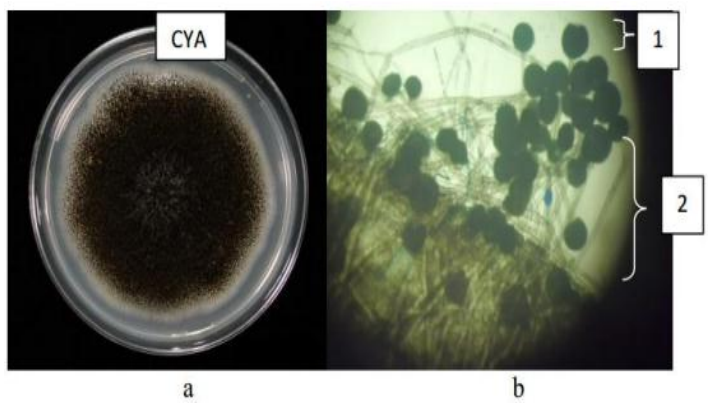

Gambar 2 Hasil pemurnian (a) isolat Aspergillus niger yang ditumbuhkan pada media CYA, (b) Foto mikrograf morfologi Aspergillus niger perbesaran 40x. 1 = vesikula, metula, fialid dan konidium, $2=$ konidiofor

Miselium Eurotium chevalieri berwarna kuning terang, seringkali lebih gelap di bagian tengahnya, menyelubungi kleistotesium berwarna kuning dan berlimpah, dilapisi oleh kepala konidium yang jarang sampai berlimpah. Koloni berwarna hijau keabuan; kleistotesium berwarna kuning terang, bulat, berdiameter 100-140 $\mu \mathrm{m}$, diselubungi oleh hifa vegetatif berwarna kuning hingga oranye; askospora berwarna kuning, bentuk menjorong (ellipsoidal) berbentuk seperti roda kerekan, panjang 4.5-5 $\mu \mathrm{m}$, berdinding halus, dengan dua flens yang menyolok, paralel, sempit, kadang-kadang berliku; konidiofor berasal dari hifa aerial, panjang tangkai 400-700 $\mu \mathrm{m}$, berdinding tipis, vesikula berdiameter 25-35 $\mu \mathrm{m}$, fertil di seluruh permukaannya, hanya membentuk fialid yang berbentuk seperti ampula, panjang 5-8 $\mu \mathrm{m}$, konidium menjorong atau berbentuk seperti tong anggur (barrel), panjang 4-5.5 $\mu \mathrm{m}$, dengan dinding berstruktur seperti duri kecil. 


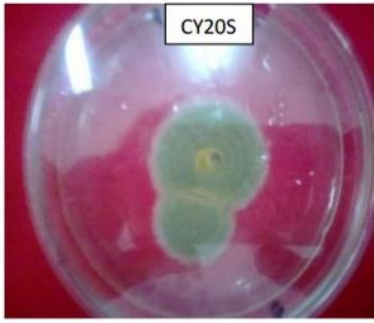

a

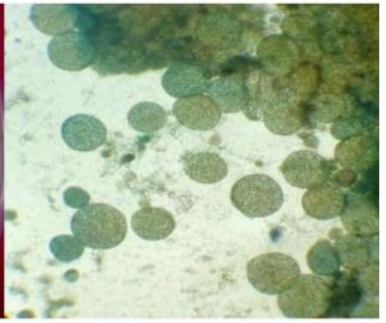

Gambar 3 Hasil pemurnian (a) isolat Eurotium chevalieri yang ditumbuhkan pada media CY20S, (b) Foto mikrograf morfologi Eurotium chevalieri perbesaran 40x berupa kleistotesium yang berisi askus dan di dalam askus terdapat 8 askospora

Setelah ditumbuhkan pada media CYA, koloni Syncephalastrum rasemosum meliputi seluruh cawan petri, berwarna abu-abu, sporangiofor ditopang oleh hifa, stipe panjang dan bercabang atau diproduksi sebagai sisi pendek cabang subur hifa; kepala sporangial berdiameter $30-80 \mathrm{~mm}$, dengan sporangiospor yang terbentuk dalam garis tunggal dalam kantung silinder (merosporangia) ditopang pada spikula sekitar vesikel, vesikel berbentuk bulat dengan diameter $10-50 \mathrm{~mm}$, berdinding halus kecuali pada titik sambungan merosporangium, biasanya runtuh teratur; sporangiospor berantai hingga 10, ukuran dan berbentuk tidak teratur berbentuk bulat hingga silinder, dengan diameter 3.0$5.0 \mathrm{~mm}$ dan berdinding halus.

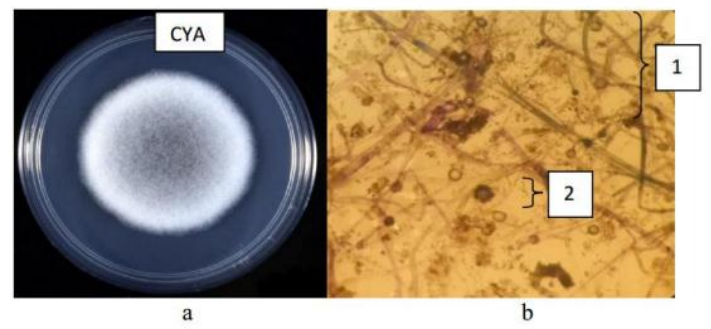

Gambar 4 Hasil pemurnian (a) isolat Syncephalastrum rasemosum yang ditumbuhkan pada media CYA,

(b) Foto mikrograf morfologi Syncephalastrum rasemosum perbesaran 40x. 1= sporangiofor, $2=$ merosporangium, sporangiospora.

Persentase biji kacang tanah yang terserang cendawan Aspergillus flavus pada media AFPA tertinggi terdapat pada jenis kacang tanah KTA dan KTC sebesar $62 \%$ dan $36 \%$, hal ini dapat terjadi karena tingginya persentase biji yang rusak pada kedua jenis kacang tanah tersebut yaitu sebesar $41 \%$ dan 50\% sedangkan untuk jenis kacang tanah KTC, persentase biji kacang tanah yang terserang Aspergillus flavus pada media AFPA sebesar $20 \%$.

A. flavus merupakan kapang yang hidup di tanah dan merupakan kapang gudang, sehingga apabila kondisi lingkungannya cukup menguntungkan, maka perkembangan dan pertumbuhannya akan sangat cepat. Rendahnya biji kacang tanah yang terserang Aspergillus flavus disebabkan oleh kecilnya persentase biji yang rusak.

Tabel 3 Persentase biji kacang tanah yang terserang Aspergillus flavus pada media AFPA 


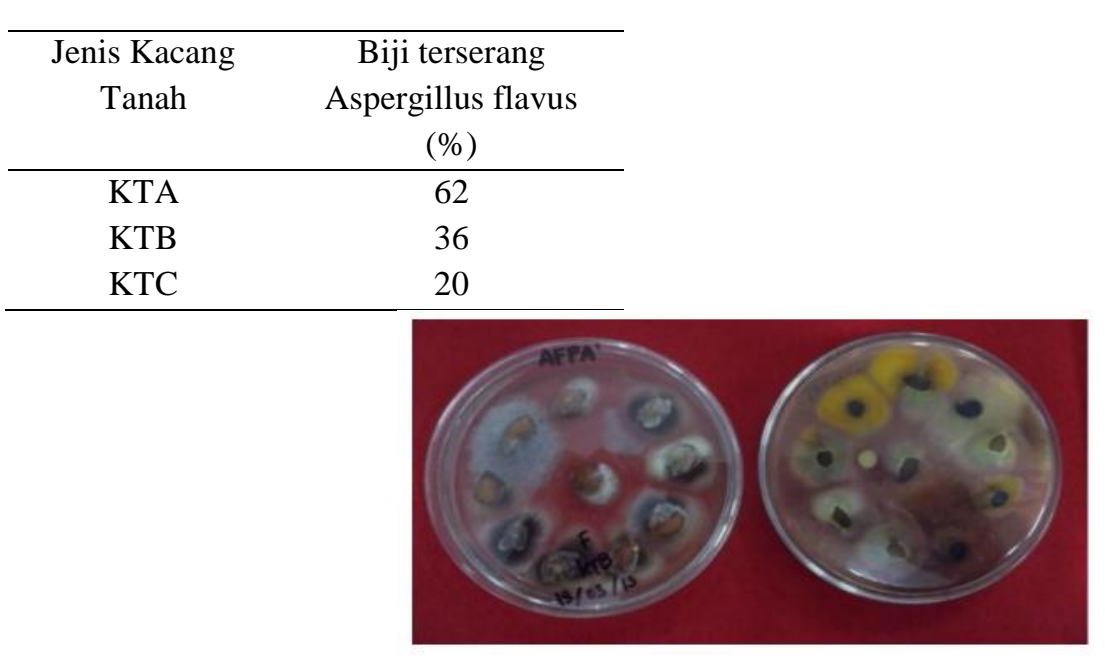

Gambar 5. Isolasi cendawan Aspergillus flavus dari biji kacang tanah pada media AFPA

Konidiofor A. flavus memiliki panjang konidiofor $400 \mu \mathrm{m}-1 \mathrm{~mm}$, berdinding kasar, vesikula bulat berdiameter $20-45 \mu \mathrm{m}$, fertil pada tiga perempat permukaannya, membentuk metula dan fialid, tetapi pada beberapa isolat sebagian kepala hanya membentuk fialid, ukuran metula dan fialid sama, panjang 7-10 $\mu \mathrm{m}$; konidium bulat sampai agak bulat, biasanya berdiameter 3.5-5 $\mu \mathrm{m}$, dengan dinding yang relatif tipis, agak kasar; sklerotium pada awalnya putih, menjadi keras dan coklat kemerahan sampai hitam, membulat dengan diameter 400-800 $\mu \mathrm{m}$.

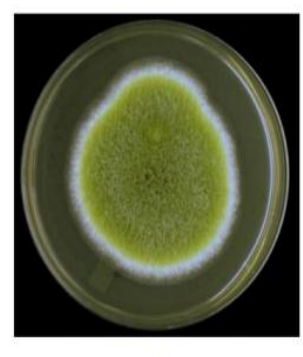

a

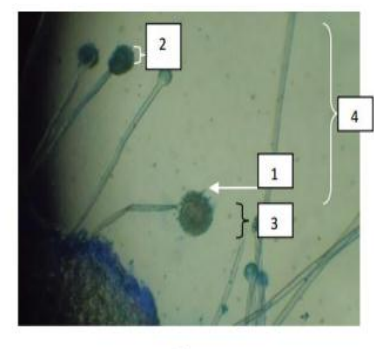

b

Gambar 6 Hasil pemurnian (a) isolat Aspergillus flavus yang ditumbuhkan pada media CYA, (b) Foto mikrograf morfologi Aspergillus flavus perbesaran 40x. 1= konidia; $2=$ vesikula, $3=$ metula, fialid dan konidium, $4=$ konidiofor

Keberadaan biji rusak pada awal penyimpanan disebabkan antara lain oleh penyortiran yang tidak dilakukan secara sempurna sebelum biji kacang tanah dikemas. Cendawan menyerang biji utuh dengan terlebih dahulu melakukan penetrasi pada kulit biji, merusak testa, dan embrio, serta mendekomposisi granula pati pada endosperma. Kacang tanah pada berbagai kultivar yang dianalisis, kandungan aflatoksin paling tinggi terdapat pada biji rusak. Kelembaban dan suhu merupakan faktor utama kontaminasi pascapanen A. flavus terhadap komoditas pangan yang disimpan (Hell dan Mutegi, 2011).

Kadar air pada setiap jenis kacang tanah memperlihatkan kadar air yang bervariasi, pada jenis kacang tanah KTA, KTB dan KTC rataan kadar air berturut-turut sebagai berikut: 6.95, 6.70, dan 8.00. Kadar air biji kacang tanah dalam kesetimbangan 
dengan kelembaban relatif ruang penyimpanan dan kadar air kacang tanah yang aman untuk sekitar 6 - 8\%. sedangkan kelembaban relatif juga dipengaruhi oleh suhu penyimpanan. Jika kelembaban relatif dipertahankan pada $70 \%$ pada suhu $25-27{ }^{\circ} \mathrm{C}$, kacang tanah dapat disimpan selama 1 tahun (Waliyar et al., 2008). Aktivitas biologis selama penyimpanan harus diminimalkan untuk menjaga kualitas kacang tanah dengan pengeringan maksimal sehingga menghasilkan kelembaban $<10 \%$, eliminasi aktivitas serangga (meningkatkan kadar air melalui kondensasi kelembaban yang dihasilkan oleh respirasi serangga) dan suhu dijaga tetap rendah.

Biji kacang tanah dengan kadar air yang tinggi akan melakukan respirasi dengan aktif, sehingga viabilitasnya cepat menurun. Panas dan uap air yang dihasilkan dari proses tersebut semakin meningkatkan suhu dalam tempat penyimpanan, sehingga memacu biji untuk semakin aktif berespirasi, juga merangsang pertumbuhan cendawan. Cendawanpun melakukan respirasi yang menghasilkan panas dan uap air, sehingga kondisi lingkungan kian buruk bagi biji itu sendiri. Akibatnya penyimpanan biji dengan kadar air tinggi (di atas keseimbangan RH 65\%) sangat berbahaya bagi biji di tempat penyimpanan. Kadar air yang lebih dari $8 \%$ dapat secara intensif diserang oleh cendawan dan mikroba lain sehingga penyimpanan kacang tanah di tempat kering dan bersih perlu diperhatikan untuk mengurangi akumulasi aflatoksin (Rahmianna et al., 2007).

Persentase biji kacang tanah yang terserang cendawan didominasi oleh beberapa spesies antara lain Aspergillus flavus, A. niger, Eurotium chevalieri, dan Synchepalastrum rasemosum. Cendawan yang menyerang jenis kacang tanah KTA dan KTC dengan persentase tertinggi adalah cendawan Aspergillus niger sedangkan cendawan yang menyerang jenis kacang tanah KTB dengan persentase tertinggi adalah cendawan Eurotium chevalieri. Christensen et al., (1992) melaporkan bahwa selama enam bulan penyimpanan biji kacang tanah sebanyak 15 spesies cendawan telah diisolasi dari semua perlakuan yaitu Aspergillus flavus, A. niger, A. penicillioides, A. tamarii, A. versicolor, A. wentii, Cladosporium cladosporioides, Eurotium chevalieri, E. repens, E. rubrum, Mucor hiemalis, Penicillium citrinum, Syncephalastrum racemosum, Trichoderma harzianum dan Wallemia sebi.

Menurut Christensen et al., (1992) peningkatan persentase biji rusak selama penyimpanan antara lain disebabkan oleh serangan cendawan. Perbedaan tingkat serangan serangga dan cendawan pada kacang tanah diduga disebabkan oleh perbedaan penanganan pascapanen dan umur penyimpanan (Dharmaputra et al., 2013). Selain itu, kerentanan biji kacang tanah terkontaminasi oleh aflatoksin akibat serangan serangga dan cendawan juga disebabkan oleh jadwal musim tanam. Dharmaputra et al., (2007) melaporkan bahwa kandungan aflatoksin B1 kacang tanah pada musim hujan lebih luas daripada musim kemarau.

Persentase biji kacang tanah yang terserang cendawan Aspergillus flavus pada media AFPA tertinggi terdapat pada jenis kacang tanah KTA dan KTC sebesar $62 \%$ dan 
$36 \%$, hal ini dapat terjadi karena tingginya persentase biji yang rusak pada kedua jenis kacang tanah tersebut yaitu sebesar $41 \%$ dan 50\% sedangkan untuk jenis kacang tanah KTC, persentase biji kacang tanah yang terserang Aspergillus flavus pada media AFPA sebesar 20\%. A. flavus merupakan kapang yang hidup di tanah dan merupakan kapang gudang, sehingga apabila kondisi lingkungannya cukup menguntungkan, maka perkembangan dan pertumbuhannya akan sangat cepat.

Rendahnya biji kacang tanah yang terserang Aspergillus flavus disebabkan oleh kecilnya persentase biji yang rusak. Selain rendahnya jumlah persentase biji yang rusak, rendahnya biji kacang tanah yang terserang Aspergillus flavus juga dapat disebabkan oleh persentase populasi Aspergillus niger sebesar 75\% pada jenis kacang KTC. Dharmaputra (2003) melaporkan bahwa A. niger merupakan cendawan yang paling potensial dalam menghambat pertumbuhan $A$. flavus toksigen. Selain itu juga dilaporkan oleh Wicklow et al., (1980) bahwa ketika A. parasiticus atau A. ochraceus tumbuh bersama sama A.flavus, hal ini tidak mempengaruhi produksi aflatoksin, tetapi jika $A$. flavus tumbuh bersamasama A. niger atau Trichoderma viride, ia tidak akan memproduksi aflatoksin. Aspergillus flavus pada media AFPA menghasilkan koloni yang berwarna kuning keoranyean hal ini dapat terjadi karena adanya reaksi dari senyawa yang dihasilkan oleh A. flavus berupa senyawa asam aspergilat dengan feri amonium sitrat yang terdapat pada media AFPA. Produksi aflatoksin tidak hanya dapat ditekan oleh pertumbuhan cendawan A. niger atau Trichoderma viride tetapi juga oleh pertumbuhan Lactobacillus casei dan Pseudomonas fluorescens, Bacillus cereus, B. Thuringiensis (Akocak et al., 2015).

\section{KESIMPULAN}

Berdasarkan hasil penelitian persentase biji yang rusak pada sampel KTA, KTB dan KTC berturut-turut sebagai berikut: $41 \%$, 50\%, dan 30.7\%. Kadar air bervariasi pada sampel kacang tanah KTA, KTB dan KTC, rataan kadar air berturut-turut sebagai berikut: $6,95,6,70$, dan 8,00. Persentase biji kacang tanah yang terserang cendawan didominasi oleh beberapa spesies antara lain Aspergillus flavus, A. niger, Eurotium chevalieri, dan Synchepalastrum rasemosum.

\section{SARAN}

Perlu adanya penelitian lanjutan dengan menambah jumlah pasar tradisional sebagai lokasi pengambilan sampel kacang tanah atau mengambil sampel kacang tanah langsung pada daerah pertanian pasca panen.

\section{DAFTAR PUSTAKA}

Antika SRV, Astuti LP, Rachmawati R. 2014. Perkembangan Sitophilus oryzae L. (coleoptera: curculionidae) pada berbagai jenis pakan. Jurnal HPT 2, 77-84. 
Akocak PB, Churey JJ, Worobo RW. 2015. Antagonistic Effect of Chitinolytic Pseudomonas and Bacillus on Growth of Fungal Hyphae and Spores of Aflatoxigenic Aspergillus Flavus. Food Bioscience 10, 48-58.

Christensen CM, Miller BS, Johnston JA, 1992. Moisture and Its Measurement. In: Sauer DB, (Ed), Storageof Cereal Grains and Their Products. American Association of Cereal Chemist. Minnesota.

Diao E, Dong H, Hou H, Zhang Z, Ning Ji, Ma W. 2015. Factors Influencing Aflatoxin Contamination in Before and After Harvest Peanuts: A Review. Journal of Food Research 4, 148-154.

Didwania N, Joshi M. 2013. Mycotoxins: A Critical Review on Occurrence and Significance. Int J Pharm. Pharm Sci. 5, 1014-1019.

Dharmaputra OS, Putri ASR, Retnowati I, Ambarwati S. 2003. Control of Aflatoxigenic Aspergillus flavus in Peanut Using Nonaflatoxigenic A. flavus, A. niger, and Trichoderma harzianum. Biotropia 21, 32-44.

Dharmaputra OS, Retnowati I, Ambarwati S. 2007. Aspergillus flavus Infection and Aflatoxin Contamination in Peanuts at Various Stages of The Delivery Chains in Wonogiri Regency, Central Java, Indonesia. Biotropia 14, 9-21.

Dharmaputra OS, Ambarwati S, Retnowati I, Windyarani A. 2013. Kualitas Fisik, Populasi Aspergillus flavus, dan Kandungan Aflatoksin B1 pada Biji Kacang Tanah Mentah. J Fitopatol Indones 9, 99-106.

Duran RM, Cary JW, Calvo AM. 2009. The Role of veA in Aspergillus flavus Infection of Peanut, Corn and Cotton. The Open Mycology Journal 3, 27- 36.

Hell K, Mutegi C. 2011. Aflatoxin Control and Prevention Strategies in Key Crops of sub- Saharan Africa. African Journal of Microbiology Research 5, 459-466.

Kasno A. 2009. Pencegahan Infeksi A. Flavus dan Kontaminasi Aflatoksin pada Kacang Tanah. Iptek Tanaman Pangan 4, 194-201.

Klich MA, Tang S, Denning DW. 2009. Aflatoxin and Ochratoxin Production by Aspergillus Species Under Ex Vivo Conditions. Mycopathologia 168, 185-191.

Kuniholm MH, Lesi OA, Mendy M, Akano AO, Sam O, Hall AJ, Whittle H, Bah E, Goedert JJ, Hainaut P, Kirk GD. 2008. Aflatoxin exposure and viral hepatitis in the etiology of liver cirrhosis in the Gambia, West Africa. Environ Health Perspect 116, 1553-1557.

Kusumaningrum HD, Suliantari, Toha AD, Putra SH, Utami AS. 2010. Cemaran Aspergillus flavus dan Aflatoksin pada Rantai Distribusi Produk Pangan Berbasis Jagung dan Faktor yang Mempengaruhinya. J Teknol dan Industri Pangan. 19, 171- 176.

Mellon JE, Cotty PJ, Dowd MK. 2007. Aspergillus flavus Hydrolases: Their Roles in Pathogenesis and Substrate Utilization. Appl Microbiol Biotechnol 77, 497-504. 12. 
Paramawati R , Arief RW, Triwahyudi S. 2006. Upaya Menurunkan Kontaminasi Aflatoksin B1 pada Kacang Tanah dengan Teknologi Pascapanen (Studi Kasus di Lampung). Jurnal Enjiniring Pertanian 4, 1-8.

Patino BA, Gonzales-Salgado MA, Jaen G, Vazquez C. 2005. PCR Detection Assays for The Ochratoxinproducing Aspergillus carbonarius and Aspergillus ochraceus Species. Int. J. Food Microbiol 104, 207-214.

Pitt JI, Hocking AD. 1997. Fungi and Food Spoilage. Springer. London.

Rachmawati E. 2012. Kandungan Aflatoksin (B1, B2, G1 dan G2) pada Kacang Tanah (Arachis hypogaea L.) yang Beredar di Pasar Tradisional Daerah Jabotabek. [S.Si. Skripsi]. Universitas Pakuan. Bogor.

Rahmianna AA, Taufiq A, Yusnawan E. 2007. Effect of Harvest Timing and Postharvest Storage Conditions on Aflatoxin Contamination in Groundnuts Harvested from The Wonogiri Regency in Indonesia Indonesian. SAT ejournal 5, 1-3.

[SNI] Standar Nasional Indonesia. 7385:2009. 2009. Batas Maksimum Kandungan Mikotoksin dalam Pangan.Badan Standardisasi Nasional. Jakarta

Waliyar F, Kumar PL, Ntare BR, Diarra B, Kodio O. 2008. Pre-and post-harvest Management of Aflatoxin Contamination in Peanuts. In: Leslie JF, Bandyopadhyay R, Visconti A. (eds.). 209-218. Mycotoxins: Detection Methods, Management, Public Health and Agricultural Trade. CABI Publishing. Walingford.

Wang J, Liu X. 2007. Contamination of Aflatoxins in Different Kinds of Foods in China. Biomed Environment Sci 20, 483-487.

Wicklow DT, Hesseltine CW, Shotwell OL, Adams GL. 1980. Interference competition and aflatoxin levels incorn. Phytopathology 78, 68-74. 